\section{JOURNAL OF THE SOUTH AFRICAN} INSTITUTION OF CIVIL ENGINEERING

Vol 58 No 1, March 2016, Pages 34-42, Paper 1279

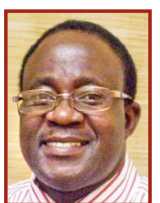

PROF STEPHEN EKOLU (Pr Eng, MSAICE, NRF rated C2) is Associate Professor of concrete materials and structures, and Head of the School of Civil Engineering and the Built Environment at the University of Johannesburg. After obtaining his BSc in engineering, he worked for government and in industry for six years as a civil engineer on building construction, materials research and testing. He then obtained an MSC (Eng) with distinction from the University of Leeds, UK, and a PhD from the University of Toronto, Canada. His research interests include concrete technology, material science aspects of concrete, durability and service life modelling of concrete structures.

\section{Contact details:}

School of Civil Engineering and the Built Environment

Department of Civil Engineering Science

University of Johannesburg

PO Box 524, Auckland Park 2006, South Africa

T: +27 11559 4405/3511, E: sekolu@uj.ac.za

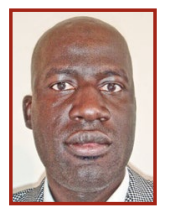

DR SOULEYMANE DIOP (Pr Nat Sci, MSAIEG, IMAEG), who holds an MSC and a PhD from the University of Tsukuba in Japan, is a Chief Scientist at the Council fo Geoscience, South Africa. He has more than fifteen years of research experience in engineering geology, geotechnical engineering, geohazards, environmental hydrology and risk assessment. He conducts various engineering-geological and geotechnical research and investigations including construction materials studies.

\section{Contact details:}

Council for Geoscience

280 Pretoria Street, Silverton, Pretoria 0001, South Africa

T: +27 12841 1168, E: sdiop@geoscience.org.za

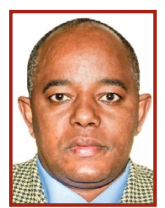

FIREHIWOT AZENE (Pr Nat Sci, P Lic-Geo) has over ten years of experience in geological engineering. He holds an MEng Geological Engineering degree from the University of British Columbia, and an MSC Hydrogeology and GDE Geotechnical Engineering from overseas universities. He was formerly a Senior Scientist at the Council for Geoscience, South Africa.

Contact details:

Council for Geoscience

280 Pretoria Street, Silverton, Pretoria 0001, South Africa

T: +1 604850 0364, E: fzegeye@gmail.com

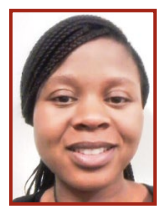

NOMVELO MKHIZE (Pr Nat Sci) is an engineering geologist at the Council for Geoscience in Pretoria. Her engineering-geological investigations include site studies and research on construction materials.

Contact details:

Council for Geoscience

280 Pretoria Street, Silverton, Pretoria 0001, South Africa

T: +27 12841 1082, E: nmkhize@geoscience.org.za

\title{
Disintegration of concrete construction induced by acid mine drainage attack
}

\author{
S O Ekolu, S Diop, F Azene, N Mkhize
}

This paper presents findings from microanalytical investigation conducted on disintegrated concrete that had been used to construct a weir within a coal mine in South Africa. The concrete was in contact with polluted mine water, commonly referred to as acid mine drainage (AMD). Accordingly, the weir had been exposed to AMD decant which led to disintegration of concrete due to chemical attack. Investigations were conducted by optical microscopy (OM), scanning electron microscopy (SEM) equipped with energy dispersive X-ray spectrometry (EDX), and $X$-ray diffraction (XRD). The field samples examined consisted of soft, broken concrete chunks and a whitish powdery substance that had crystallised and formed a surface coating on certain cracked locations on the deteriorated concrete. No evidence of pyrite oxidation was found in the investigation. The observed deterioration is discussed in relation to acid attack mechanism and its possible co-existence with external sulphate attack process.

\section{INTRODUCTION}

Acid mine drainage (AMD) refers to polluted, typically acidic mine water formed from oxidation of sulphidic ores from mining works, which at later stages undergo chemical reactions under atmospheric conditions. In recent years AMD has become a serious problem in South Africa, as in other countries with mining activities, due to concerns regarding its impacts on the environment and on infrastructure (IMC-AMD 2010). AMD typically occurs decades after mining activities have been abandoned at the mining site, and poses no immediate problem. However, it is the discharge of AMD from its source of formation to the surrounding environment and water courses that creates the problem. For underground mines, AMD may pollute groundwater aquifers which usually provide quality water for industrial and domestic consumption. Underground mines may also decant the polluted water to the surface, as has been the case in the South African goldfields. Surface mines and tailings can also cause discharge of AMD at the earth's surface level, directly or indirectly impacting the environment and its inhabitants (McCarthy 2011).

Among other effects, AMD can be expected to cause detrimental impacts on engineering infrastructure, including corrosion of plumbing and water conveyance systems, corrosion of pumps and water pumping equipment, and the deterioration of roads, bridges and other highway structures. Some concrete structures are also used at mining sites, although on a relatively small scale, and it is in this regard that the observed degradation of the field concrete occurred (Azene \& Ekolu 2012).

In the literature, problems resulting from the presence of sulphate-bearing aggregates in concrete have generally been well established and studied quite significantly. It is known that sulphate-bearing minerals of pyrites and pyrrhotites undergo oxidation, producing sulphuric acid and degradation within the cementitious matrix (Oberholster et al 1984; Bromley 2015; Rodrigues et al 2012; Tagnit-Hamou et al 2005; Cody et al 1997; Thomas et al 1989; Shayan 1988; Ayora et al 1998). However, there are hardly any research papers concerning the interaction between AMD and concrete. Perhaps the rarity of these scenarios is related to the typically remote location of AMD sources, being found in mines far removed from the areas of massive infrastructure. The closest past investigations of this kind, conducted on AMD-concrete interactions, were laboratory experiments by Breitenbucher and Siebert (2008). In their study, AMD was simulated using acid-sulphate solutions made using varied concentrations of iron (II) sulphide $\left(\mathrm{FeSO}_{4}\right)$ and sulphuric acid. They found that solutions containing high sulphate concentrations from iron (II) sulphates exhibited acid attack at values in the $\mathrm{pH}$ range of 4. Although AMD has recently become quite a significant issue in South Africa, there is little or hardly any research so far done concerning its effect on infrastructure materials. This paper directly links degradation of concrete construction in the field to an attack by AMD from the mines. 


\section{Acid mine drainage}

There are different forms of acids that may cause attack on concrete, ranging from weak acids such as acetic, carbonic, lactic, tannic and phosphoric acids, to strong acids namely nitric, sulphuric and hydrochloric acids. In the current investigation, acidic (mine) water under study is a by-product of pyritic oxidation typically emanating from abandoned mining works and resulting from exposure of pyrites $\left(\mathrm{FeS}_{2}\right)$ to oxygen and moisture. It may be emphasised that the formation of sulphuric acid (or the AMD) is a cyclic process of regeneration leading to its continuous discharge, until the pyrites are exhausted or the support environmental conditions terminate. Understanding of the AMD formation process was mainly recognised in the 1980-90s (Bromley 2015; Howie 1979, 1992; Newman 1998). This reaction process is explained by Equations 1 to 3 (Bromley 2015; Pankaj et al 2011).

$2 \mathrm{FeS}_{2}+7 \mathrm{O}_{2}+2 \mathrm{H}_{2} \mathrm{O} \rightarrow$

$2 \mathrm{FeSO}_{4}+2 \mathrm{H}_{2} \mathrm{SO}_{4}$

$4 \mathrm{FeSO}_{4}+\mathrm{O}_{2}+2 \mathrm{H}_{2} \mathrm{SO}_{4} \rightarrow$

$2 \mathrm{Fe}_{2}\left(\mathrm{SO}_{4}\right)_{3}+2 \mathrm{H}_{2} \mathrm{O}$

$7 \mathrm{Fe}_{2}\left(\mathrm{SO}_{4}\right)_{3}+\mathrm{FeS}_{2}+8 \mathrm{H}_{2} \mathrm{O} \rightarrow$

$15 \mathrm{FeSO}_{4}+8 \mathrm{H}_{2} \mathrm{SO}_{4}$

Initially pyrites react with oxygen and water to produce ferrous (iron II) oxide and sulphuric acid (also sulphate), as shown in Equation 1. With abundant presence of atmospheric oxygen and moisture, the ferrous ions convert to ferric iron, both forms existing in dissolved state (Equation 2). The ferric oxide formed from Equation 2, may further oxidise additional pyrites, creating a cycle of continuous acid generation, given in Equation 3. Additionally, a bacterial species thiobacillus ferrooxidans is known to oxidise iron and sulphur in pyrites at a low $\mathrm{pH}<3.5$. At later stages, after the formation of AMD and during its discharge into the environment, hydrolysis may occur, depending on the $\mathrm{pH}$ level of the solution. If the AMD is highly acidic with low $\mathrm{pH}<3.5$, then little or no hydrolysis may occur. At higher $\mathrm{pH}$, the ferric (iron III) oxide will convert to ferric hydroxide, which then precipitates out of solution as a brownish-orange rust-like product.

The stages defined by Equations 1 to 3 represent the generic process by which AMD forms. In a typical case, the AMD formed seeps through various rock strata as it flows from its reaction sites to the general environment, and in the process dissolves certain metals from rocks and other materials within its pathway. These dissolved metals then become incorporated into the AMD's chemical composition. Accordingly, AMD is typically characterised by high acidity, high content of heavy metals, high amounts of dissolved solids and high sulphate concentrations. In AMD, sulphates are primarily in the form of iron disulphate. While other types of sulphates, such as sodium sulphate or magnesium sulphate, are known to cause severe attack in concrete, it has been shown that iron disulphate appears not to inflict major damage or expansive attack under acidsulphate conditions (Breitenbucher \& Siebert 2008). The chemical signature of AMD is more complex than the composition of mineral acids. For this reason AMD can be viewed as an acid or acidic water of a unique category; it cannot therefore be expected to behave precisely as mineral acids, due to possible interactions that could result from its various dissolved ions.

\section{Possible mechanisms of concrete attack by acid mine drainage}

Considering the typical chemistry of AMD, which consists of high acidity and high sulphate concentration, the postulated AMD damage attack on concrete may take the forms of acid attack and/or sulphate attack mechanisms.

\section{Acid attack in concrete}

When an acid comes into contact with concrete, the first line of attack arises from the reaction of the acid with portlandite (calcium hydroxide $-\mathrm{CH}$ ) leading to the formation of calcium sulphate (i.e. gypsum) and water. In the case of sulphuric acid, the reaction may be written as in Equation 4 (Zivica \& Bajza 2001):

$$
\mathrm{H}_{2} \mathrm{SO}_{4}+\mathrm{Ca}(\mathrm{OH})_{2} \rightarrow \mathrm{CaSO}_{4}+2 \mathrm{H}_{2} \mathrm{O}
$$

It is generally acknowledged that the second phase, involving destruction of tobermorite or C-S-H, will only follow after portlandite dissolution (Hill et al 2003; Sersale et al 1998). The second phase is a more advanced and severe acid attack, above and beyond the effects arising from portlandite dissolution alone. It is essential to note here that the reaction product of acid attack is principally gypsum. However, other sulphate-bearing reaction products may also be present in smaller quantities. Acid attack on concrete is generally exhibited at $\mathrm{pH}<6.5$ (Fattuhi \& Hughes 1983), but becomes severe and more pronounced at $\mathrm{pH}$ levels of 3 to 4 , which is the range of $\mathrm{pH}$ values that were determined for the AMD under this investigation (Azene \& Ekolu 2012). According to DIN 4030 (2008), the degree of water aggressiveness is considered to be severe for a $\mathrm{pH}$ range of 4.5 to 5.5 , and very severe for $\mathrm{pH}<4.5$ (Ekolu \& Azene 2012; Earlie \& Callaghan 1988).

For groundwater, the conditions suggestive of potential acid attack are water of $\mathrm{pH} \leq 5.0$, total acidity of $\geq 25 \mathrm{mg}$ per $100 \mathrm{~g}$ of soil, and a sufficient groundwater rate of replenishment (Earlie \& Callaghan 1988; Bearly 1980). The acid will typically attack and destroy the concrete surface, but the latter will in turn tend to neutralise the acid due to the high alkalinity of concrete (Ekolu et al 2013; Makhloufia et al 2014). A fresh supply of acid will launch further attacks progressively into the interior of concrete (Woodson 2009; Attiogbe \& Rizkalla 1988). Most concrete structures also contain steel reinforcement which is protected by a concrete cover of about $50 \mathrm{~mm}$ thick. Corrosion of the cover concrete would expose the reinforcement, not only to acid attack, but also to steel corrosion.

Studies have shown that, upon exposure of cementitious systems to acidic media over a prolonged period of time, the physical damage that ensues is characteristically associated with loss in mass, loss in compressive strength, and increase in porosity and permeability (Fattuhi \& Hughes 1983; Attiogbe \& Rizkalla 1988; Fattuhi \& Hughes 1988; Adesanya \& Raheem 2010; Senhadji et al 2014). These properties are symptomatic of the underlying intrinsic degradation of chemical phases, which may only be confirmed through microanalysis. Indeed, studies using SEM/EDX and XRD show that microstructural damage due to acid attack typically exhibits microcracking, often infilled predominantly by a whitish product of reaction, gypsum (Senhadji et al 2014; Song et al 2005; Rendell \& Jauberthie 1999; Tulliania et al 2002; Hasan 2009; Xie et al 2004).

\section{Sulphate attack in concrete}

External (as opposed to internal) sulphate damage would be the most likely form of sulphate attack relevant to the AMD scenario. From understanding of hydration reactions of cement, the most predominant phases present in hardened concrete are monosulphate, tobermorite $(\mathrm{C}-\mathrm{S}-\mathrm{H})$ and portlandite, along with unreacted cement compounds and ettringite. In the process of external sulphate attack, the sulphate ions from an external source (in this case AMD) penetrate into concrete. These ions then react with free and abundantly available portlandite in the ground mass of concrete, forming gypsum, which in turn reacts with monosulphate to form ettringite (Thomas \& Skalny 2006; Tian \& Cohen 2000; Al-Amoudi 2002), as given in Equation 5: 
$\mathrm{C}_{3}$ A.CŠ. $\mathrm{H}_{12}+2 \mathrm{CS}^{\mathrm{S}} \mathrm{H}_{2}+16 \mathrm{H} \rightarrow$ (monosulphate) (gypsum)

$\mathrm{C}_{3} \mathrm{~A} .3 \mathrm{CS} . \mathrm{H}_{32}$

(ettringite)

Hence, in a cementitious system subject to sulphate attack, ettringite is the predominant reaction product (perhaps with some presence of gypsum), generating expansive pressures reported to be in the range of $8 \mathrm{MPa}$, depending on the sulphate concentration (Müllauer et al 2013). These high pressure levels by far exceed the tensile strength of concrete, which can be as low as $2 \mathrm{MPa}$ (Kong \& Evans 1980). Accordingly, the formation of gypsum and ettringite minerals is expansive, leading to disruption of the concrete matrix, and is characterised by mass increase, cracking and disintegration, as well as strength loss (Santhanam et al 2003; Ekolu \& Ngwenya 2014a, 2014b; Ekolu 2014).

The common different types of sulphate salts known to cause attack in concrete are typically $\mathrm{Na}_{2} \mathrm{SO}_{4}$ (Glaubers salt), $\mathrm{MgSO}_{4}$ (Epsom salts) and $\mathrm{CaSO}_{4}$ (Gypsum). For an AMD signature that has a high concentration of iron, the dominant sulphate compound would most likely be $\mathrm{FeSO}_{4}$ (iron sulphate). But studies have shown that $\mathrm{FeSO}_{4}$ may not be as damaging or expansively attacking as the alkaline-based sulphate compound forms (Breitenbucher \& Siebert 2008). In those sources of AMD where alkalis such as sodium, potassium or magnesium may be present in significant concentrations, normal sulphate attack could be possible. It can therefore be surmised that the possibility of sulphate attack depends on the source (and therefore chemical composition) of the AMD.

\section{BACKGROUND TO THIS INVESTIGATION}

While conducting field survey of an abandoned coal mine, the authors of the current study observed severe exfoliation of a concrete weir that was in contact with AMD (Figure 1). A detailed description of the field inspection undertaken was given in an earlier publication (Azene \& Ekolu 2012), when an index assessment for AMD aggressiveness was conducted. This paper presents a microanalytical study of concrete samples that were taken from site and subjected to examination with the aim of identifying the possible mechanism of attack. The study was conducted using OM, XRD and SEM fitted with EDX.

\section{FIELD SAMPLES}

The samples used in this investigation were AMD and deteriorated concrete specimens

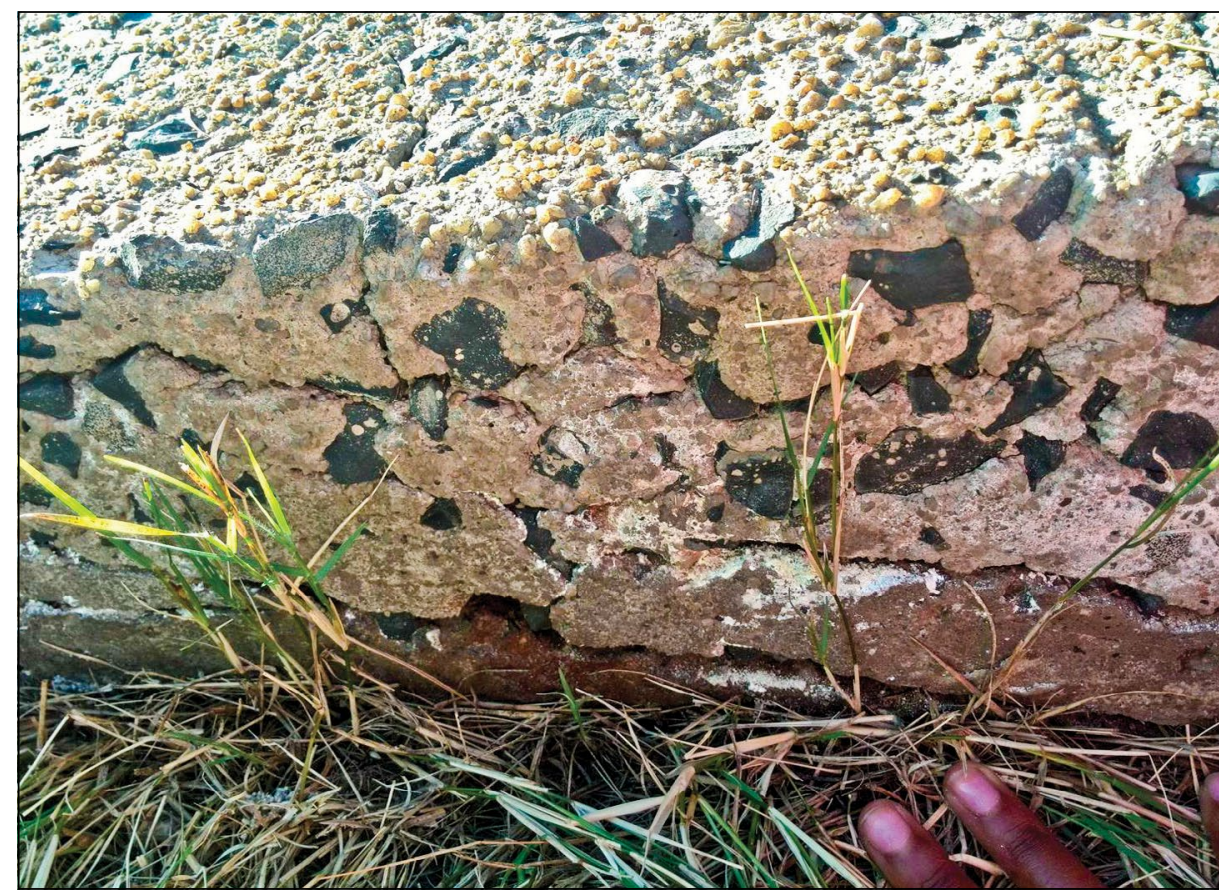

Figure 1 Disintegrated concrete weir at a site of acid mine drainage decant (Azene \& Ekolu 2012)

Table 1 Chemical composition and pH of the acid mine drainage (Azene \& Ekolu 2012)

\begin{tabular}{|c|c|c|c|c|c|c|c|c|c|c|c|}
\hline $\mathbf{p H}$ & $\begin{array}{c}\mathbf{E C} \\
\mathbf{m S} / \mathbf{m}\end{array}$ & $\begin{array}{c}\mathrm{CaCO}_{\mathbf{3}} \\
\mathbf{m g} / \mathbf{l}\end{array}$ & $\begin{array}{c}\mathrm{Cl} \\
\mathbf{m g} / \mathbf{l}\end{array}$ & $\begin{array}{c}\mathbf{P} \\
\mathbf{m g} / \mathbf{l}\end{array}$ & $\begin{array}{c}\mathrm{SO}_{\mathbf{4}} \\
\mathbf{m g} / \mathbf{l}\end{array}$ & $\begin{array}{c}\mathrm{Fe} \\
\mathbf{m g} / \mathbf{l}\end{array}$ & $\begin{array}{c}\mathbf{C a} \\
\mathbf{m g} / \mathbf{l}\end{array}$ & $\begin{array}{c}\mathbf{M g} \\
\mathbf{m g} / \mathbf{l}\end{array}$ & $\begin{array}{c}\mathbf{M n} \\
\mathbf{m g} / \mathbf{l}\end{array}$ & $\begin{array}{c}\mathbf{K} \\
\mathbf{m g} / \mathbf{l}\end{array}$ & $\begin{array}{c}\mathbf{N a} \\
\mathbf{m g} / \mathbf{l}\end{array}$ \\
\hline 3.0 & 907 & 66 & 32 & $<0.1$ & 5200 & 23 & 990 & 247 & 14 & 32 & 1168 \\
\hline
\end{tabular}

collected from the site. As described by Azene and Ekolu (2012), severe exfoliation had been exhibited in concrete above the AMD flow level, showing:

- A line of disintegration separating concrete above the AMD flow level from the foundation (Figure 1)

- A map-cracking pattern, seemingly oriented longitudinally along the length of the wall lining (the deterioration and cracking occurred across the $250 \mathrm{~mm}$ thick wall of the concrete weir, due to AMD penetration (Figure 1)

- Swelling and spalling of the concrete leading to falling out of disintegrated chunks of concrete

- Depositions of powdery salt crystals on the concrete surface (the surface depositions exhibited a white-yellowish discoloration)

- Erosion of cement past matrix leaving protruding aggregates.

\section{Acid mine drainage from the coal mine}

Table 1 shows the chemical composition and $\mathrm{pH}$ of AMD collected from the source of attack on concrete. The crucial parameters of the AMD are its low $\mathrm{pH}$ of 3.0 and high sulphate concentration of $5200 \mathrm{ppm}$. This degree of water aggressiveness falls under the very severe category (DIN 4030 2008; Neville 1996). It can be seen from Table 1 that the main ion species responsible for aggressiveness in the AMD were the $\mathrm{Cl}^{-}, \mathrm{Fe}^{+}$ and $\mathrm{SO}_{4}{ }^{2-}$ ions. Evidently, the concentrations of $\mathrm{Cl}^{-}$and $\mathrm{Fe}^{+}$in the water are too low to be of concern, leaving the $\mathrm{SO}_{4}{ }^{2-}$ to be the possible species with potential to inflict damaging attack, especially considering the high sodium concentration. However, it was of interest in this study to determine whether the active mechanism was acid attack, sulphate attack or combined acid and sulphate attack processes. It may be noted that use of the term "acid" in AMD does not necessarily imply that all forms of AMD are acidic. In fact, some forms of AMD, referred to as neutral mine drainage (NMD), are not acidic at all and have a neutral $\mathrm{pH}$ (Heikkinen $e t$ al 2009; Pope et al 2010; Lindsay et al 2015). The potential for NMD or AMD attack on concrete, metals or any other materials, depends on its geological source, which in turn relates to its chemical signature.

\section{Concrete samples and reaction products}

The exfoliation of concrete was observed at upper layers of the weir, above the AMD flow level, as described in Azene and Ekolu (2012). The concrete was severely exfoliated, to the extent that it softened and crumbled, and could be easily broken off by hand. The crumbled pieces of concrete were collected and used for analytical studies. Another interesting feature of deterioration was the whitish powder crusts of a reaction product 


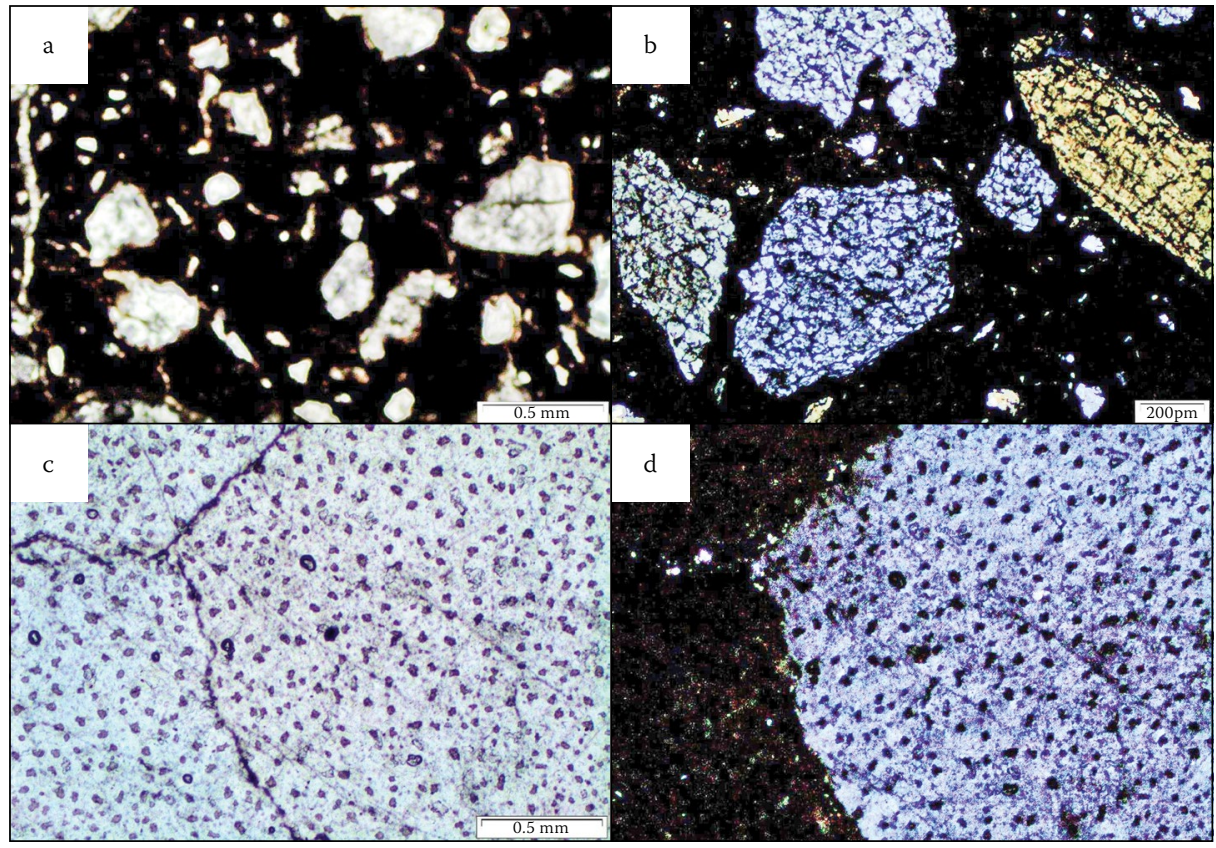

Figure 2 Photomicrographs of thin sections showing aggregate types and features under plane polarised light: (a) predominant presence of quartz particles, (b) severely weathered quartz particles, (c) fractured aggregate devoid of infilling, (d) same as (c) but viewed at higher magnification

formed at the surface of the severely cracked concrete. At the site, samples of the powder salts were scraped from the concrete surface using a dry, clean wooden stick. The collected samples were then placed in plastic bags and sealed before transporting for analytical investigation in the laboratory.

Non-destructive testing of the concrete using the Schmidt hammer method (Neville 1996; Breccolotti et al 2013) found its compressive strengths to be in the range of $20 \mathrm{MPa}$. The concrete was made using $22 \mathrm{~mm}$ maximum coarse aggregates.

\section{ANALYTICAL STUDIES AND DISCUSSIONS}

The three main techniques that were used in microanalysis and petrographic examination of the deteriorated field concrete consisted of OM, XRD and SEM/EDX. Different samples of the field concrete were prepared in the laboratory, and used for analytical studies.

\section{Optical microscopy (OM)}

Thin sections were prepared from the concrete chunk samples and examined using an optical microscope Olympus BX41TF, with high-resolution imaging capabilities of up to 400x magnification, equipped with an Olympus Camera SC100. Petrographic examination showed characteristics of a severely altered concrete matrix exhibiting distinct features of deterioration.

\section{Aggregates}

Petrographic examination revealed the presence of predominantly quartz aggregates and opaque minerals, as the main types of aggregates used in the concrete mixtures. Figure 2a illustrates the typical quartz aggregates identified in the damaged concretes. Evidently the aggregates are circumvented by a network of cracks, as discussed later. Figure $2 \mathrm{~b}$ gives a closer view of the aggregate surface features. It can be seen that the quartz particles are severely weathered, indicating a likely leaching away of surface material, including cement paste and the associated phases. Leaching is a highly likely possibility, given the exposure of the concrete to flowing AMD which then caused erosion of leachable phases both from the cement matrix and aggregate surface. There was also an observation of fractured quartz aggregate particles as seen in Figure 2c. However, no infilling of the fracture was evident. A close-up of the fractured particle, shown in Figure 2d, shows a good bond between the particle and the cement paste, but there appears to be concentration of unreacted pyrites lining along the aggregate rim and further into an opaque mineral aggregate. In Figure 3a, sulphate bearing minerals, most likely pyrite and pyrrhotite, can be seen distributed throughout the opaque mineral aggregate. This feature can be seen further at a higher magnification given in Figure 3b, clearly showing a widely disseminated (pale yellow) pyrite within the opaque aggregate particle.

\section{Microcracking and expansive mineral phases}

Thin sections were also examined for the presence of microcracks and expansive phases. Figure 4 gives microscopic images of microcracking observed in thin sections of the deteriorated concrete samples. In Figures $4 \mathrm{a}$ and $4 \mathrm{~b}$, microcracks can be seen circumventing the aggregate particles, undertaking to follow aggregate rims, which in non-deteriorated concrete is a typically weak interfacial transition zone (ITZ) comprising large depositions of calcium hydroxide relative to the $\mathrm{CH}$ present in the mortar or concrete matrix (Scrivener \& Pratt 1994; Ollivier et al 1995; Harutyunyan et al 2000). The interconnected cracks run directly through the paste matrix, forming a multidirectional crack network. All the microcracks along the ITZ and paste matrix are infilled with a mineral phase, later identified through SEM analysis to be gypsum. It may be emphasised that this observation was not an isolated case, but rather a characteristic feature. The visibly fibrous gypsum infilling, perpendicularly oriented to the crack walls, indicates exertion of expansive pressure during the phase growth. In Figure $4 \mathrm{~b}$ an infilled crack can be seen running through a severely weathered and sutured quartz particle, as well as around its rim. This appears to be an isolated case where the particle may have been fractured mechanically or due to weathering. In this case, the microcrack and its gypsum infilling opportunistically developed its path through the fractured particle. There is no evidence within, or at the aggregate rims, suggesting that the particles may be involved in an expansive reaction.

In Figure 5, a map-cracking pattern is evident, but also present are oriented parallel cracks, especially seen in Figure 5a. This combination of map and parallel microcracks is consistent with the cracking patterns that were observed during physical examination of the exfoliated concrete weir, as shown in Figure 1.

\section{Scanning electron microscopy (SEM)}

The SEM examination allows characterisation of the phase morphology, which usually provides useful information in phase identification. The EDX gives elemental information and their relative proportions. This information is often used to confirm a distinct presence of specific phases. Concrete is a heterogeneous material with several inherent phases consisting of pores, unhydrated cement phases, hydration products and minerals, and aggregates. Various forms of attack on concrete, such as sulphate attack, acid attack, etc, typically introduce new phases that are not normally present in substantial quantities within the hardened cementitious system. In microanalysis, such unusual phases can be identified and examined. 
In this investigation, SEM analyses were conducted using a Leica 440 Stereoscan SEM equipped with an INCA (OXFORD) EDX. Fractured samples of the deteriorated concrete were used in order to view image features free of disturbances such as polishing. Samples were cleaned using acetone, air-dried and mounted onto an SEM stub by means of an adhesive, then carbon coated. Image analysis was conducted in backscattered electron image (BSE) mode, so as to obtain some qualitative information related to composition.

Figure 6a gives a BSE image of deteriorated concrete taken from the field site. The main mineral phase seen in the micrograph is gypsum. Also seen in the image is contamination associated with clay and plant material intermixtures. The identified quartz is a phase from the sand used in the concrete, confirming observations made by petrographic examination. The dominant presence of gypsum in the pore structure is unusual in normal concrete and represents a likely attack process. It is also evident that gypsum forms the major groundmass product of the micrograph. Figure $6 \mathrm{~b}$ shows the associated EDX spectra for the various phases identified. It can be seen (Figure 6b) that the EDX spectra for gypsum is mainly calcium (Ca), sulphur (S) and oxygen (O), which form the main elemental composition of the mineral phase. Similarly, fine aggregate of quartz consists predominantly of silica $\left(\mathrm{SiO}_{2}\right)$. The other spectra are for the clay and plant contaminants found intermixed in the concrete. Further SEM analysis, using another sample taken from the deteriorated field concrete, is given in Figure 7 in the form of an electron micrograph and the associated EDX spectra of the major phases observed. Again, the electron micrograph shows an infilling of gypsum as the dominant product in the groundmass of the matrix. The morphology of the gypsum consists of crumbled, packed crystals being perhaps an indication of the existence of expansive pressures exerted against the crack walls. Also evident in Figure 7 is a trigonal hexagonal phase, likely to be calcite. This phase was detected through XRD analysis, as shown in Figure 8. No other sulphate-bearing phases such as ettringite or thaumasite were observed. It may be noted that thaumasite formation necessitates the presence of carbonates in concrete, along with its exposure to low temperatures typically below $4^{\circ} \mathrm{C}$. Both of these conditions did not exist at the site of this study, and therefore thaumasite formation would be unlikely. Also not observed were any rust product phases, such as goethite $(\mathrm{FeO}(\mathrm{OH}))$,

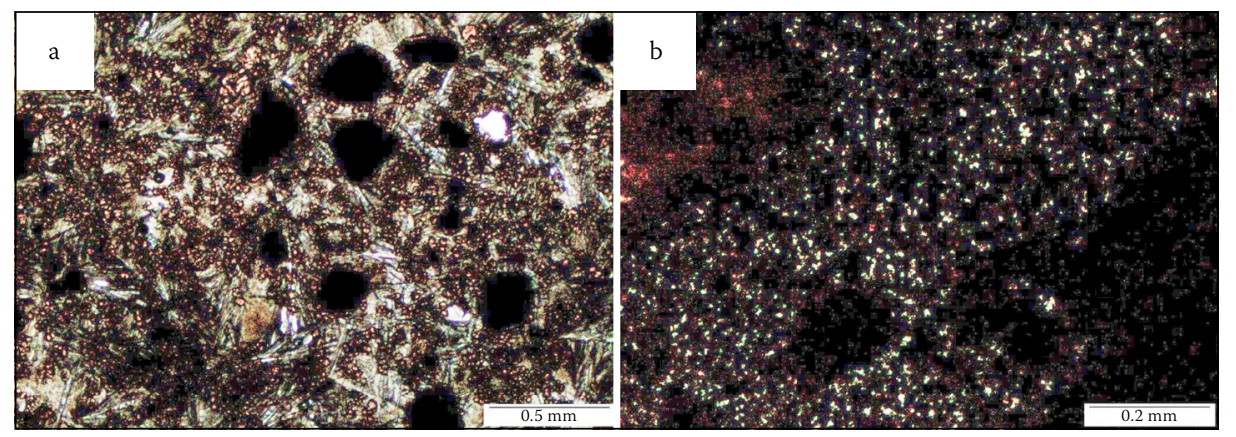

Figure 3 Photomicrographs of thin sections showing sulphate-bearing minerals under plane polarised light: (a) opaque minerals, (b) a close-up of (a) highlighting disseminated pyrites in an opaque particle under cross-polarised light

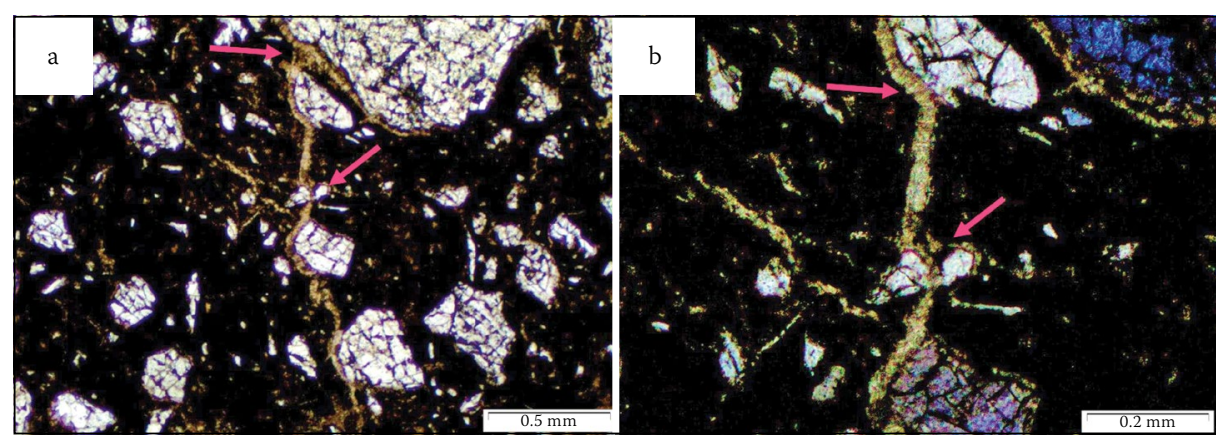

Figure 4 Photomicrographs of thin sections showing: (a) microcracks and infilling under plane polarised light, (b) a close-up of (a) highlighting microcracking running through or over a sutured quartz particle in cross-polarised light

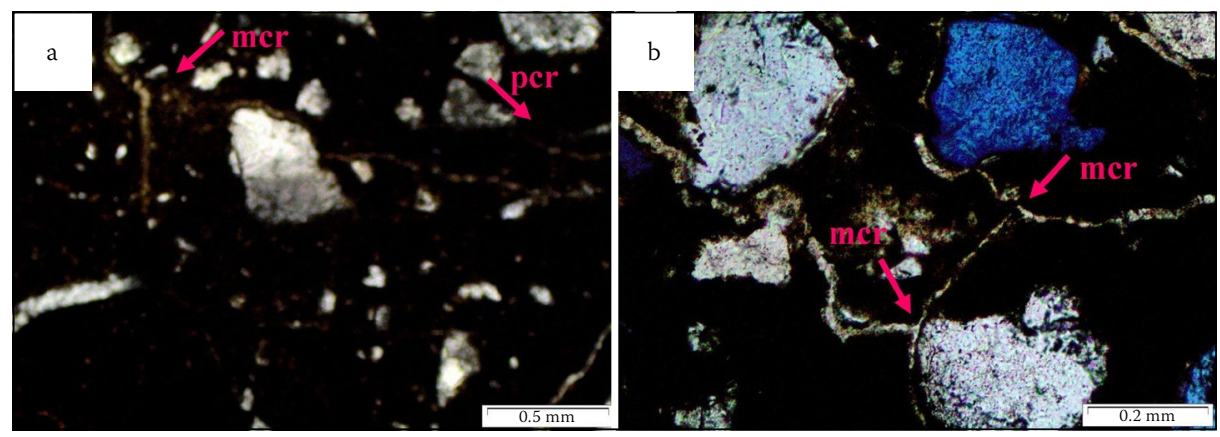

Figure 5 Photomicrographs of thin sections showing: (a) map patterns and parallel microcracks viewed under plane polarised light, (b) a close-up highlighting multidirectional mapcracking and infilling of cracks under cross-polarised light (mcr - map cracks, pcr parallel cracks)

Ferrihydrite $\left(\mathrm{Fe}(\mathrm{OH})_{3}\right)$ or hematite $\left(1 / 2 \mathrm{Fe}_{2} \mathrm{O}_{3}\right)$, which rules out possible involvement of pyrite oxidation in the attack.

\section{X-ray diffraction (XRD)}

Samples broken off from the mortar matrix of disintegrated concrete were oven-dried at $50^{\circ} \mathrm{C}$ for seven days, then ground with mortar and pestle into fine powder, passing a $90 \mu \mathrm{m}$ sieve. The powder samples were back-loaded into the sample holders and analysed. A BRUKER D8 Advance Powder $\mathrm{X}$-ray diffractometer was used with copper radiation, $\mathrm{CuK} \alpha$ (wavelength $\lambda=1.5418 \AA$ )

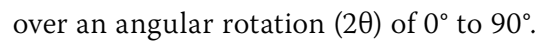
The XRD analysis determined the final reaction products and phases predominantly present in the cementitious system. Figure 8 shows the XRD patterns for the disintegrated concrete samples. The samples comprised phases that were identified to be quartz, gypsum and calcite. In both spectra shown, it is interesting to note that no portlandite was found among the phases identified. This implies that this phase is likely to have reacted to form calcite under carbonation, and/or to form gypsum, the latter being the reaction product of $\mathrm{CH}$ with AMD. Furthermore, ettringite, which is an opportunistic phase that is usually present in concrete, was generally not found. These changes in the matrix products of concrete are important indications of the chemical reactions that could have led to the observed disintegration of the concrete. Again, no traces of rust products, such as goethite, ferrihydrite or hematite were detected, which also excludes the possible presence of pyrite oxidation as participant in attacking the cementitious system. 


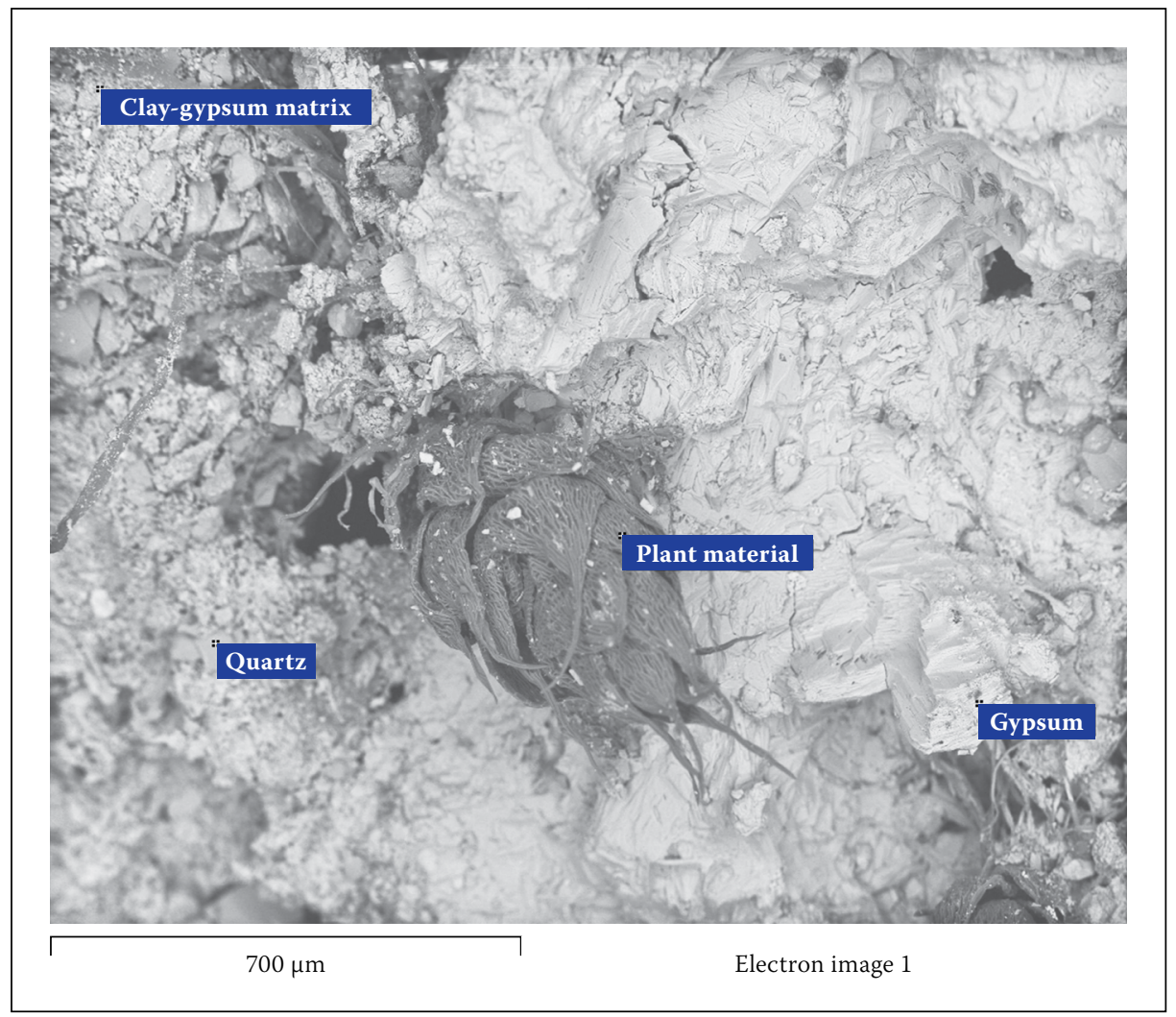

Figure 6a SEM image of the deteriorated concrete sample
Discussion of the attack process

The AMD was shown to be of low $\mathrm{pH}$ of 3.0 and high sulphate concentration of 5200 ppm, as given in Table 1. Accordingly, sulphate attack or acid attack processes on the concrete would be likely, as discussed earlier. This high sulphate concentration of 5200 ppm of the AMD falls under severe classification (Ekolu \& Azene 2012; Earlie \& Callaghan 1988). In the XRD analysis, there was no evidence of $\mathrm{CH}$ being present in the concrete. In a normal non-deteriorated concrete matrix, $\mathrm{CH}$ is plentiful and is responsible for the high alkalinity of concrete, usually with $\mathrm{pH} \geq 12.6$.

Upon exposure of the concrete to the low $\mathrm{pH} \mathrm{AMD}$, the $\mathrm{CH}$ must have undergone reactions leading to gypsum formation, while some calcium ions may have been leached out of the concrete along with sodium and potassium alkalis, given the dynamic exposure conditions. Considering that the AMD on site was flowing at a substantial rate, there was continuous replenishment of fresh ions to maintain the attack on concrete. Evidence from XRD analysis corroborates
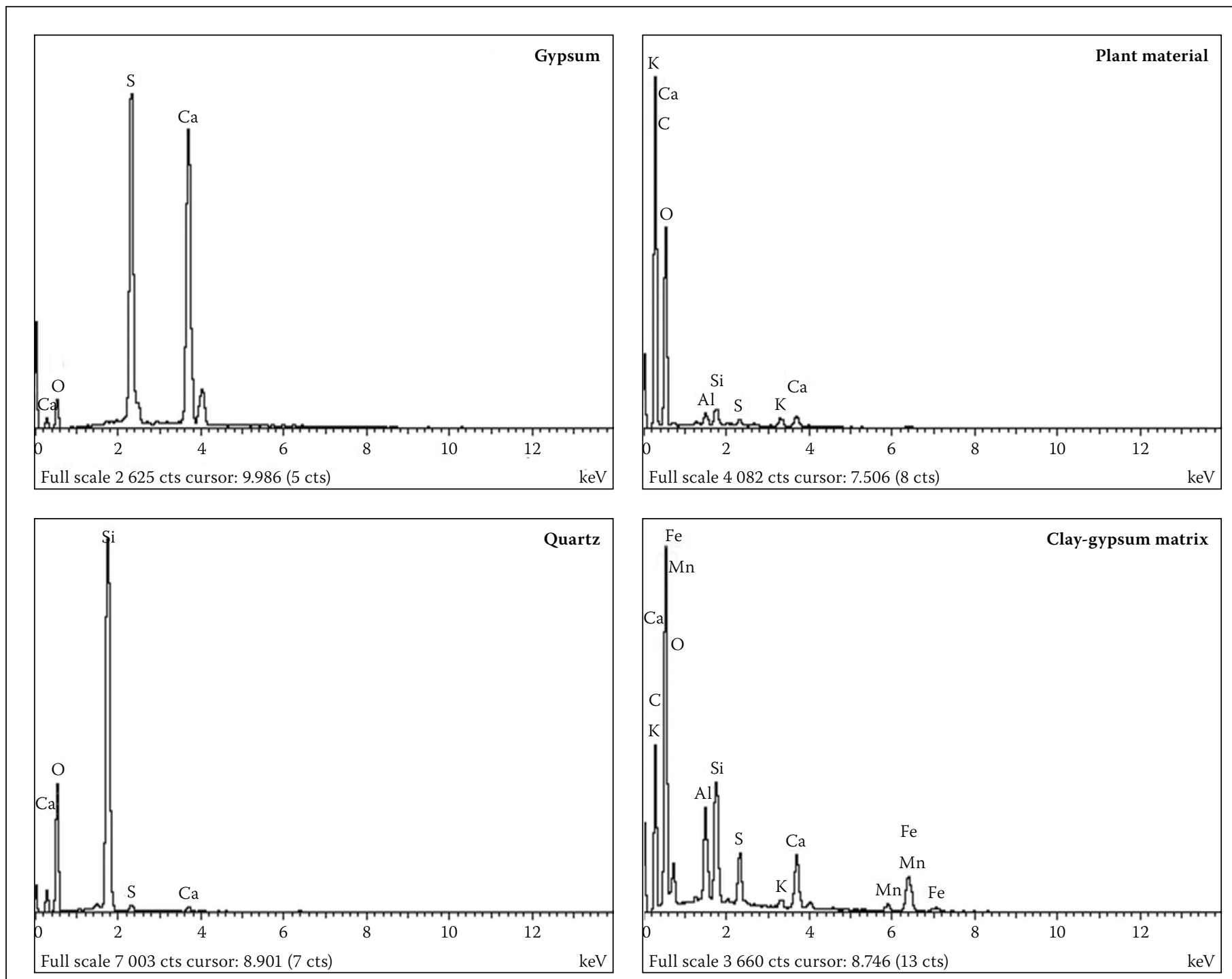

Figure $\mathbf{6 b}$ EDS spectra of various phases labeled in Figure $6 a$ 
the observations from petrography and SEM/EDX examination, singling out gypsum as the sole reaction product found in the disintegrated concrete. In Figure 1, gypsum can be seen as the white powdery substance coating the surface of exfoliated concrete. It may also be noted that the reaction product was concentrated along large cracks, most likely leached from the concrete matrix by flowing water and deposited at the crack surface layers as water evaporated.

As discussed earlier, the acid-sulphate conditions from AMD could cause competing sulphate attack and acid attack mechanisms in concrete. However, the low concentration of iron in AMD implies that most sulphates would be in the form of sulphuric acid (Equation 1), which limits potential sulphate attack due to ferrous sulphate. Also, sulphate attack due to ferrous sulphate would result in the formation of iron (ii) hydroxide, in accordance with Equation 6. However, no ferrous hydroxide was detected through analytical studies done using SEM/EDX or XRD.

$\mathrm{Ca}(\mathrm{OH})_{2}+\mathrm{FeSO}_{4}+2 \mathrm{H}_{2} \mathrm{O} \rightarrow$
$\mathrm{CaSO}_{4} \cdot 2 \mathrm{H}_{2} \mathrm{O}+\mathrm{Fe}(\mathrm{OH})_{2}$

While it remains possible that the two mechanisms of acid and sulphate attack could co-exist, considerations from the foregoing discussions, along with microanalytical studies, seem to support acid mechanism as the overriding attack process responsible for the observed degradation in the field concrete, following its exposure to AMD. These findings are also in agreement with the results of experimental work by Breitenbucher and Siebert (2008), whose investigation found acid attack mechanism to be dominant under acid-sulphate conditions. In addition, there was no observation of rust phases of goethite, ferrihydrite or hematite, indicating the absence of pyrite oxidation attack.

\section{CONCLUSIONS}

In the foregoing investigation, exfoliated field concrete that had been used in the construction of a weir was examined. The concrete weir was in contact with acid mine drainage at its source of decant in an abandoned coal mine. Over time, the concrete had severely disintegrated. Microanalytical studies were conducted on the deteriorated concrete by using optical microscopy, scanning electron microscopy and $x$-ray diffraction techniques. The main objective of the investigation was to determine the mechanism of attack that led to the concrete deterioration.

1. Petrographic examination found the concrete aggregates to be predominantly quartz particles and some opaque

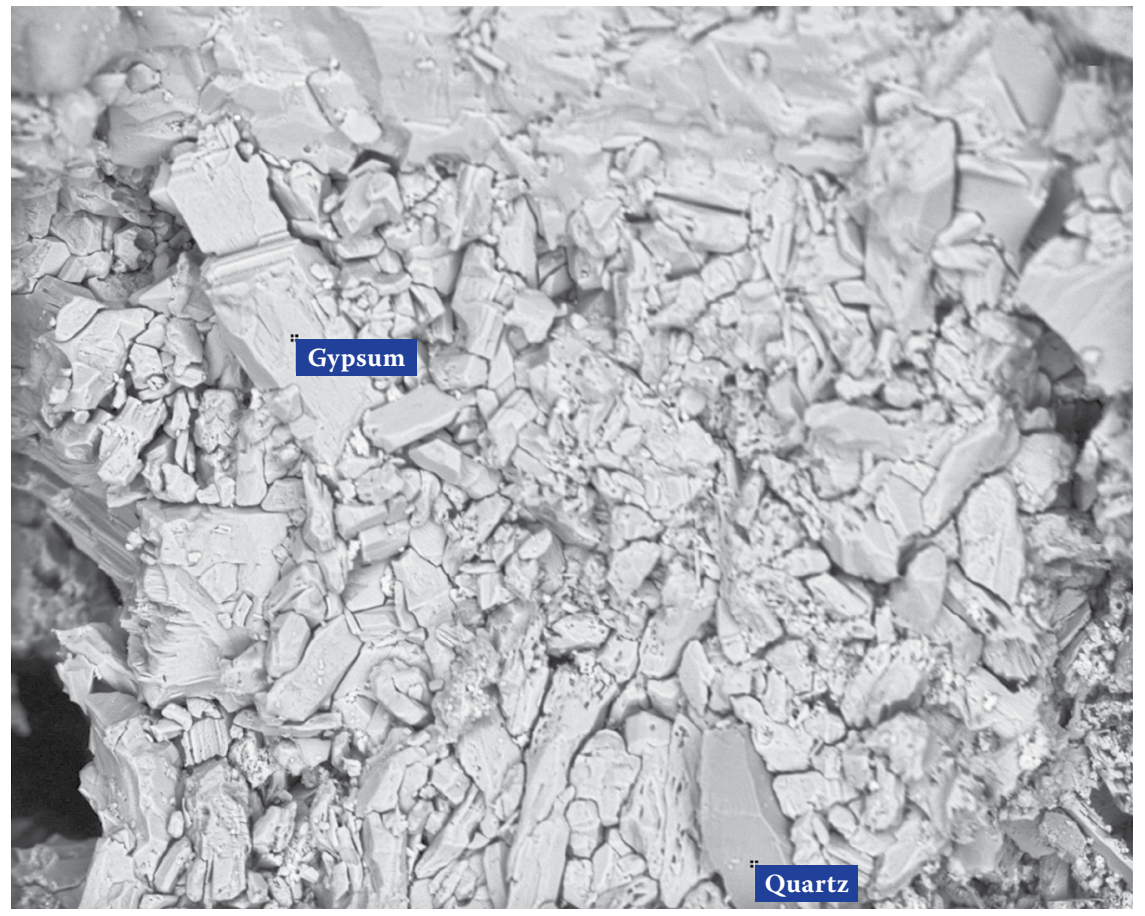

$200 \mu \mathrm{m}$

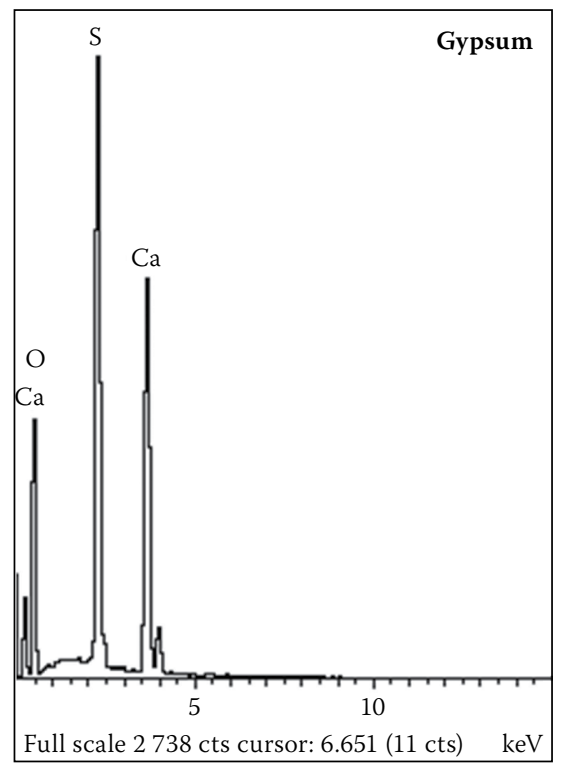

Electrom image 1

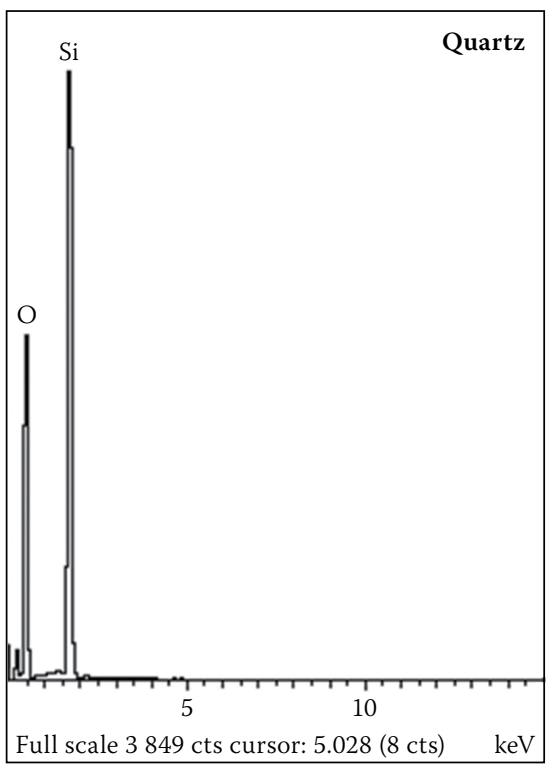

Figure 7 SEM image and EDS spectra of the deteriorated concrete

minerals. The quartz particles were found to have severely weathered, and in some cases there was evidence of mechanical fracturing. The opaque minerals were identified to be unreacted pyrites. Intense multi-directional microcracking was observed circumventing the quartz particles, by running along the interfacial transition zone and directly through the paste matrix. The microcracks were characterised by two patterns consisting of map-cracking and parallel oriented cracking.

2. The observed microcracks contained an infilling by a mineral phase, identified by scanning electron microscopy and x-ray diffraction to be gypsum. The fibrous layers of the infilling were visibly perpendicular to the crack walls. Besides that, the gypsum crystals also exhibited crumbled morphology, suggesting exertion of pressure by the crystals during expansion.

3. No rust products were found, which ruled out pyritic oxidation as a possible source of damage. Similarly, iron hydroxides were not detected through the analytical studies, which negates the possibility of ferrous sulphate attack. Gypsum was found to be the sole reaction product of attack. Acid attack appears to be the most likely damage mechanism responsible for the observed deterioration, with or without possible secondary contribution from sulphate attack. 


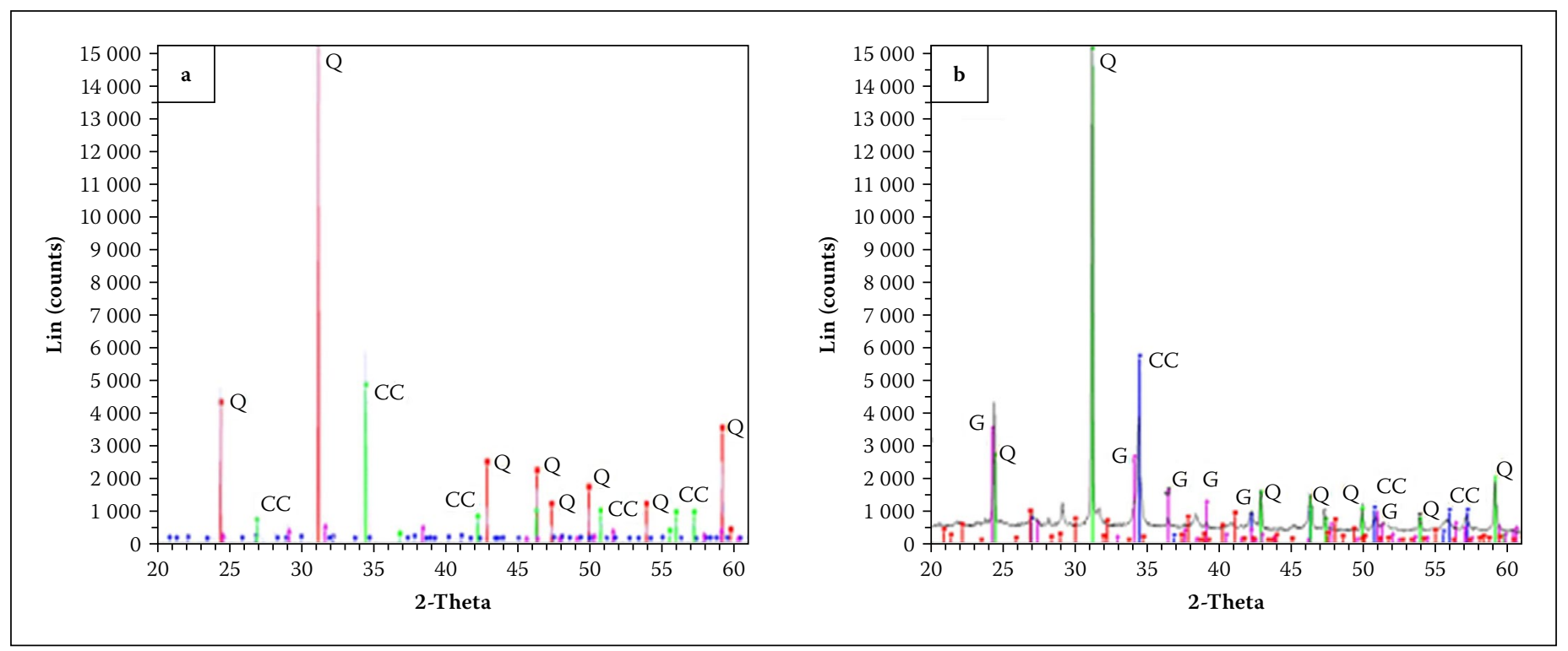

\section{Figure 8 XRD pattern of disintegrated field concrete: Q - quartz, G - gypsum, CC - calcite}

\section{ACKNOWLEDGEMENT}

The work herein presented was funded through a collaboration programme on acid mine drainage research between the University of Johannesburg and the Council for Geoscience (CGS), South Africa. The authors are grateful to the CGS for providing the research project funding.

\section{REFERENCES}

Adesanya, D A \& Raheem, A A 2010. A study of the permeability and acid attack of corn cob ash blended cements. Construction and Building Materials, 24: 403-409.

Al-Amoudi, O S B 2002. Attack on plain and blended cements exposed to aggressive sulfate environments. Cement and Concrete Composites, 24: 305-316

Attiogbe, E K \& Rizkalla, S H 1988. Response of concrete to sulfuric acid attack. ACI Materials Journal, 84.(6): 481-488.

Ayora, C, Chinchon, S, Aguado, A \& Guirado, F 1998. Weathering of iron sulfides and concrete alteration: Thermodynamic model and observation in dams from central Pyrenees, Spain. Cement and Concrete Research, 28(9): 1223-1235.

Azene, F \& Ekolu, S O 2012. Acid mine water quality The cause of deterioration observed in field concrete. Proceedings, 6th International Conference on Environmental Science and Technology (ICEST), 25-29 June, Paper No 1346.

Bearly, M 1980. Concrete Pipe Handbook. Dallas, TX: American Concrete Pipe Association.

Breccolotti, M, Bonfigli, M F \& Materazzi, A L 2013. Influence of carbonation depth on concrete strength evaluation carried out using the SonReb method. NDT \& E International, 59: 96-104.

Breitenbucher, R \& Siebert, B 2008. Concrete under combined acid and sulfate attack due to oxidation of iron disulphide. Cement International, 8: 105-110.

Bromley, A 2015. A compendium of concrete aggregates used in Southwest England.
Available at: https://projects.exeter.ac.uk/ geomincentre/09Mundic\%20Block\%202.pdf [accessed on 16 March 2015].

Cody, R D, Spry, P G, Cody, A M \& Lee, H 1997.

Expansive mineral growth and concrete deterioration. Final report for Iowa DOT Project HR-384. Ames, IA: Department of Geological and Atmospheric Sciences, Iowa State University. DIN (DIN Deutsches Institut für Normung -

German Institute for Standardization) 2008. DIN 4030 2008. Assessment of Water, Soil and Gases for their Aggressiveness to Concrete. Part 1: Principles and Limiting Values; Part 2: Sampling and Analysis of Water and Soil Samples. Berlin, Germany: DIN.

Earlie, J \& Callaghan, T 1988. Impacts of mine drainage on aquatic life, water uses, and man-made structures, Chapter 4. In: Coal Mine Drainage Prediction and Pollution Prevention in Pennsylvania. Harrisburg, PA: Department of Environmental Protection. Available at: http://www.dep.state.pa.us/ dep/deputate/minres/districts/cmdp/main.htm.

Ekolu, S O \& Azene, F 2012. A survey of corrosion and the engineering impacts of acid mine drainage on infrastructure. Technical Report to the Council for Geoscience. Johannesburg: University of the Witwatersrand.

Ekolu, S O \& Ngwenya, A 2014a. Sulphate corrosion behaviour of high volume slag concrete. Proceedings, International Conference on Construction Materials and Structures (ICCMATS), Johannesburg, 24-26 November, pp 788-796.

Ekolu, S O \& Ngwenya, A 2014b. Sulphate resistance of concrete made with moderately high alumina slag. Proceedings, International Conference on Construction Materials and Structures (ICCMATS), Johannesburg, 24-26 November, pp 797-805.

Ekolu, S O, Azene, F \& Diop, S 2013. A concrete PRB for treatment of acid mine drainage, Proceedings of the Institution of Civil Engineers (ICE) - Water Management Journal. Available at: http://www. dx.doi.org/10.1680/wama.13.00035 [accessed on 21 November 2013].
Ekolu, S O 2014. Simple criteria for evaluating sulphate attack in concrete. Proceedings, International Conference on Construction Materials and Structures (ICCMATS), Johannesburg, 24-26 November, pp 806-812.

Fattuhi, N I \& Hughes, B P 1983. Effect of acid attack on concrete with different admixtures or protective coatings. Cement and Concrete Research, 13(5): 655-665.

Fattuhi, N I \& Hughes, B P 1988. The performance of cement paste and concrete subjected to sulphuric acid attack. Cement and Concrete Research, 18(4): 545-553.

Harutyunyan, V S, Abovyan, E S, Monteiro, P J M, Mkrtchyan, V P \& Balyan, M K 2000. Microstrain distribution in calcium hydroxide present in the interfacial transition zone. Cement and Concrete Research, 30(5): 709-713.

Hasan, Md S 2009. Predicting life expectancy of concrete septic tanks exposed to sulphate and biogenic sulphuric acid attack. MEng dissertation. Melbourne, Australia: RMIT University, School of Civil, Environmental and Chemical Engineering.

Heikkinen, P M, Räisänen, M L \& Johnson, R H 2009. Geochemical characterisation of seepage and drainage water quality from two sulphide mine tailings impoundments: Acid mine drainage versus neutral mine drainage. Mine Water $\mathcal{E}$ the Environment, 28(1): 30-49.

Hill, J, Byars, E A, Sharp, J H, Lynsdale, C J, Crips, J C \& Zhou, Q 2003. An experimental study of combined acid and sulphate attack of concrete. Cement and Concrete Composites, 25: 997-1003.

Howie, F M P 1979. Physical conservation of fossils in existing collections. Newsletter of the Geological Curators' Group, 2: 269-280.

Howie, F M P 1992. Pyrite and marcasite. In: Howie, F M P (Ed), The Care and Conservation of Geological Material, Minerals, Rocks, Meteorites and Lunar Finds. Oxford: Butterworth-Heinemann. IMC-AMD (Inter-Ministerial Committee on Acid Mine Drainage) 2010. Task Force Report: Mine water management in the Witwatersrand Goldfields with 
special emphasis on acid mine drainage. Prepared by the Expert Team of the Inter-Ministerial Committee under the Coordination of the Council for Geoscience. Pretoria.

Kong, F K \& Evans, R H 1980. Reinforced and Prestressed Concrete, 2nd ed. London: Thomas Nelson.

Lindsay, M B J, Moncur, M C, Bain, J G, Jambor, J L, Ptacek, C J \& Blowes, D W 2015. Geochemical and mineralogical aspects of sulfide mine tailings. Applied Geochemistry, 57: 157-177.

Makhloufia, Z, Bederina, M, Bouhicha, M \& Kadri, E-H 2014. Effect of mineral admixtures on resistance to sulfuric acid solution of mortars with quaternary binders. Physics Procedia, 55: 329-335.

McCarthy, T 2011. The impact of acid mine drainage in South Africa. South African Journal of Science, 107(5/6): 1-7.

Müllauer, W, Beddoe, R E \& Heinz, D 2013. Sulfate attack expansion mechanisms. Cement and Concrete Research, 52: 208-215.

Neville, A M 1996. Properties of Concrete, 4th ed. New York: Wiley.

Newman, A 1998. Pyrite oxidation and museum collections: A review of theory and conservation treatments. The Geological Curator, 6(10): 363-371.

Oberholster, R E, Du Toit, P \& Pretorius J L 1984. Deterioration of concrete containing a carbonaceous sulphide-bearing aggregate. Proceedings, 6th International Conference on Cement Microscopy, 26-29 March, Albuquerque, NM.

Ollivier, J P, Maso, J C \& Bourdette, B 1995. Interfacial transition zone in concrete. A review article. Advanced Cement Based Materials, 2(1): 30-38.

Pankaj, S, Sameer, V, Sharma, S N, Mahure, N V, Anil, R, Sivakumar, N \& Murari, R 2011. Acid mine discharge - Challenges met in a hydropower project.
International Journal of Environmental Sciences, 1(6): 1274-1282.

Pope, J, Newman, N, Craw, D, Trumm, D \& Rait, R 2010. Factors that influence coal mine drainage chemistry [on the] West Coast, South Island, New Zealand. New Zealand Journal of Geology E Geophysics, 53(2/3): 115-128.

Rendell, F \& Jauberthie, R 1999. The deterioration of mortar in sulphate environments. Construction and Building Materials, 13(6): 321-327.

Rodrigues, A, Duchesne, J, Fournier, B, Durand, B, Rivard, P \& Shehata, M 2012. Mineralogical and chemical assessment of concrete damaged by the oxidation of sulphide-bearing aggregates: Importance of thaumasite formation on reaction mechanisms. Cement and Concrete Research, 42(10): 1336-1347. Santhanam, M, Cohen, M D \& Olek, J 2003. Effects of gypsum formation on the performance of cement mortars during external sulfate attack. Cement and Concrete Research, 33: 325-332.

Scrivener, K \& Pratt, P L 1994. RILEM TC 108 State-ofthe-Art Report. New York: Chapman \& Hall.

Senhadji, Y, Escadeillas, G, Mouli, M, Khelafi, H \& Benosman, C 2014. Influence of natural pozzolan, silica fume and limestone fine on strength, acid resistance and microstructure of mortar. Powder Technology, 254: 314-323.

Sersale, R, Frigione, G \& Bonavita, L 1998. Acid depositions and concrete attack: Main influences. Cement and Concrete Research, 28(1): 9-24.

Shayan, A 1988. Deterioration of a concrete surface due to the oxidation of pyrite contained in pyritic aggregates. Cement and Concrete Research, 18(5): 723-730.

Song, X J, Marosszeky, M, Brungs, M \& Munn, M 2005. Durability of fly ash based Geopolymer concretes against sulphuric acid attack. Proceedings, 10th International Conference on Durability of Building Materials and Components, 17-20 April, Lyon, France, pp 17-20.

Tagnit-Hamou, A, Saric-Coric, M \& Rivard, P 2005. Internal deterioration of concrete by the oxidation of pyrrhotitic aggregates. Cement and Concrete Research, 35(1): 99-107.

Thomas, M D A \& Skalny, J 2006. Chemical resistance of concrete. In: Lamond, J F \& Pielert, J H (Eds), STP169D: Significance of Tests and Properties of Concrete and Concrete Making Materials, West Conshohocken, PA: ASTM International, pp 253-267.

Thomas, M D A, Kettle, R J \& Morton, J A 1989. The oxidation of pyrite in cement stabilized colliery shale. Quarterly Journal of Engineering Geology, 22(3): 207-218.

Tian, B \& Cohen, M D 2000. Does gypsum formation during sulfate attack on concrete lead to expansion? Cement and Concrete Research, 30(1): 117-123.

Tulliani, J-M, Montanaroa, L, Negro, A \& Collepardi, M 2002. Sulfate attack of concrete building foundations induced by sewage waters. Cement and Concrete Research, 32(6): 843-849.

Woodson, R D 2009. Causes of distress and deterioration of concrete. In: Woodson, R D (Ed), Concrete Structures, Boston, MA: ButterworthHeinemann, pp 19-29.

Xie, S, Qi, L \& Ding, Z D 2004. Investigation of the effects of acid rain on the deterioration of cement concrete using accelerated tests established in the laboratory. Atmospheric Environment, 38: 4457-4466.

Zivica, V \& Bajza, A 2001. Acidic attack of cement based materials - A review. Part 1. Principle of acidic attack. Construction and Building Materials, 15: 331-340. 